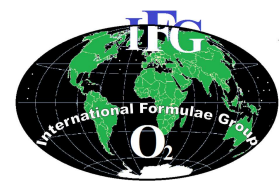

Available online at http://ajol.info/index.php/ijbes

Int. J. Biol. Chem. Sci. 8(3): 882-890, June 2014

International Journal

of Biological and

Chemical Sciences

ISSN 1997-342X (Online), ISSN 1991-8631 (Print)

Original Paper

http://indexmedicus.afro.who.int

\title{
Effect of dietary energy level on growth performance and morphometric parameters of local barred chickens at the starter phase
}

\author{
Herve Mube KUIETCHE*, Jean Raphaël KANA, Henry Fuelefack DEFANG, \\ Cyrille D'alex TADONDJOU, Divine Doriane Mane YEMDJIE and Alexis TEGUIA \\ Department of Animal Production, Faculty of Agronomy and Agricultural Sciences, University of Dschang, \\ PO Box: 188, Dschang, Cameroon. \\ *Corresponding author, E-mail: mubehervemkh@yahoo.com; Skype: hervemubekuietche, \\ Tel: + $23774596159 /+23797039142$
}

\begin{abstract}
An experiment was conducted to determine the influence of dietary energy level on the growth performance and morphometric characteristics of local barred chicks. The experiment lasted for 12 weeks. Three hundred and twenty day-old barred chicks were assigned to four different dietary treatments, having four replicates of 20 chicks each. Treatments consisted of D0, D1, D2 and D3 containing 2700, 2800, 2900 and $3000 \mathrm{kcal} / \mathrm{kg}$ of metabolisable energy respectively. The highest BW (868 g) and BWG $(830 \mathrm{~g})$ were recorded with treatment D1 and D3 (844 g and $804 \mathrm{~g}$ respectively). These values were significantly $(\mathrm{P}<0.05)$ higher compared to D0 and D2. The feed conversion ratio were significantly $(\mathrm{P}<0.05)$ higher with treatments D0 and D2 as compared to treatments D1 and D3. Feed cost per kg of body weight was significantly $(\mathrm{P}<0.05)$ lower for treatment D1 as compared to other treatments. Thus, metabolisable energy requirement of local barred chicks between 1 to 12 weeks is $2800 \mathrm{kcal} / \mathrm{kg}$.
\end{abstract}

(C) 2014 International Formulae Group. All rights reserved.

Keywords: Barred chickens, dietary energy, starter phase.

\section{INTRODUCTION}

The productivity of indigenous chickens can be improved by providing appropriate housing, disease control and good nutrition (Mbajiorgu et al., 2011; Mtileni et al., 2012). The nutritional requirements of commercial chickens, turkeys, pheasants and related poultry stock have been estimated (Yamane et al., 1980; NRC, 1994). However, informations on the protein and energy requirements of indigenous chickens are limited and most of the works done on local poultry are based on nutrient requirement of exotic breed (Kreman et al., 2012; Kana et al., 2013; Kana et al., 2014). Energy is one of the most significant components in poultry feed as far as production cost is concerned. The energy sources contribute to about $70 \%$ of the total ration of poultry (Tewe et al., 2002). It is therefore imperative that judicious formulation of poultry feed must be carried out to ensure that optimal efficiency is achieved, not only in the utilization of total feed but also in the use of its energy as well. Numerous studies on commercial broilers have demonstrated that on complete balanced 
feeds, improved growth and feed conversion efficiency could be achieved with increased level of dietary energy (Saleh et al., 2004; Ghazalah et al., 2008; Niu et al., 2009). This was also observed with the relatively slowgrowing Malaysian kampong crossbred chicken in the finishing phase (Engku, 2007). During the post-hatching or starter phase (121 days), some researches have also been conducted on the response of the village chick to dietary energy level (Nguyen and Bunchasak, 2005; Engku et al., 2011; Magala et al., 2012; Alabi et al., 2013). The results obtained have not been consistent. While Alabi et al. (2013) on South Africa Venda chicks showed that high energy diet promoted greater weight gain than the low energy feed, no difference in growth response was observed with increasing energy content from 2500 to $3000 \mathrm{kcal} / \mathrm{kg}$ as reported by Engku et al. (2008) on 21 day-old Malaysian Kampung chicks. With the Cameroon local barred chickens, none of such work has been reported. This study was therefore carried out to investigate the effect of various dietary energy levels on the productivity of local barred chickens in their starter phase.

\section{MATERIALS AND METHODS}

\section{Study area}

The study was carried out between February and April 2012 at the Teaching and Research Farm of the University of Dschang (LN 5 to $7^{\circ}$, LE 8 to $12^{\circ}$ ). Dschang is located in the Western Sudano-Guinean Savannah of Cameroon at $1500 \mathrm{~m}$ above sea level. Wind speed mean is $1.60 \mathrm{~m} / \mathrm{s}$, mean temperature is $20{ }^{\circ} \mathrm{C}$ and relative humidity varies between 60 - 80\%. Annual rainfall varies between 1910 and $2010 \mathrm{~mm}$. The raining season runs from mid-March to mid-November and the dry season from mid-November to mid-March.

\section{Experimental animals, diets and data collection}

A total of 500 eggs from a stabilized population (F2) of local barred chickens were incubated according to commercial practices in small scale manual incubator. From the above incubation, 320-day-old barred chicks were used in this study. Birds were randomly distributed to 4 dietary groups, with 4 replications of 20 chickens each in a completely randomized design. Artificial heat for the first 14 days was provided by the used of electric bulbs. Chicks were allocated on a littered floor poultry house in an open system under the same management conditions. Water and feed were offered ad libitum. The experiment lasted 12 weeks.

Experimental diets consisted of D0, D1, D2 and D3 containing 2700, 2800, 2900 and $3000 \mathrm{kcal} / \mathrm{kg}$ of metabolisable energy respectively (Table 1 ).

Feed intake (FI) and life body weight (BW) for individual chicks were recorded weekly; body weight gain (BWG) was obtained by the difference in BW of two consecutive weeks according to the procedures of McDonald et al. (2011). Feed conversion ratio (FCR) was obtained by dividing weekly FI by weekly BWG. The price of $\mathrm{kg}$ of feed was given starting from the price of the raw materials available on the local market. Feed cost per kg of body weight (FC) was obtained by multiplying the price of $\mathrm{kg}$ of feed by the FCR over the same period. The data on body measurement were taken at the end of the experiment. This measurement included: body length, wing length, comb length, comb height, beak length, head length, body girth, tarsus diameter, tarsus length and wattle height. These parameters were measured and recorded according to Yarubu and Salako (2009) and Ajayi et al. (2012) using a tape rule $(\mathrm{cm})$. Body length was measured from the tip of the beak through the body trunk to the tail. Body girth was measured as the circumference of the breast region, while the wing length was the distance from the scapula joints to the last digits of the wing and tarsus length was measured from the hock joint to the metatarsal pad. 


\section{Statistical analysis}

Data collected were subjected to one way analysis of variance (ANOVA) to compare treatment means at probabilities of $5 \%$. When differences were declared significant among means, they were separated using the Duncan Multiple Range Test (Steel and Torrie, 1980).

\section{RESULTS}

The effect of energy level on feed intake, body weight, weight gain, feed efficiency and cost of feed necessary to produce a $\mathrm{kg}$ of body weight is summarized in Table 2.

Feed intake was not significantly $(\mathrm{P}>$ $0.05)$ affected by the energy level of the diet. However, increasing dietary energy level tends to reduce feed intake. Thus, chicks in the group D0 receiving the lowest energy level $(2700 \mathrm{kcal} / \mathrm{kg})$ recorded the highest but non-significant feed intake as compared to birds fed D1, D2 and D3.

Dietary energy level had a significant effect $(\mathrm{P}<0.05)$ on $\mathrm{BW}$ and $\mathrm{BWG}$ of chickens. Animals in groups D1 and D3 recorded significantly highest $(\mathrm{P}<0.05) \mathrm{BW}$ and BWG as compared to birds in groups D0 and D2. The growth curves or BW were similar in all groups. However, the growth curves of animals subjected to diets D1 and D3 were above those subjected to diet D0 containing $2700 \mathrm{kcal}$ and D2 containing 2900 kcal (Figure 1).

Increasing the energy level of the diets tend to lower feed efficiency of the local barred chicks at starter phase. Feed conversion ratio (FCR) and feed cost per $\mathrm{kg}$ of body weight $(\mathrm{FC})$ were significantly $(\mathrm{P}<0.05)$ higher for birds fed diets D0 and D2 compared to treatments D1 and D3.

\section{Morphometric parameters}

Except for the height and length of the comb and the height of the wattles, dietary energy level significantly affected $(P<0.05)$ all body measurements (Table 3 ). Increasing dietary energy level tends to increase the values of body measurements. However, the highest $(\mathrm{P}<0.05)$ head length was obtained with the chicks in group D0 $(2700 \mathrm{Kcal})$ as compared to other groups.

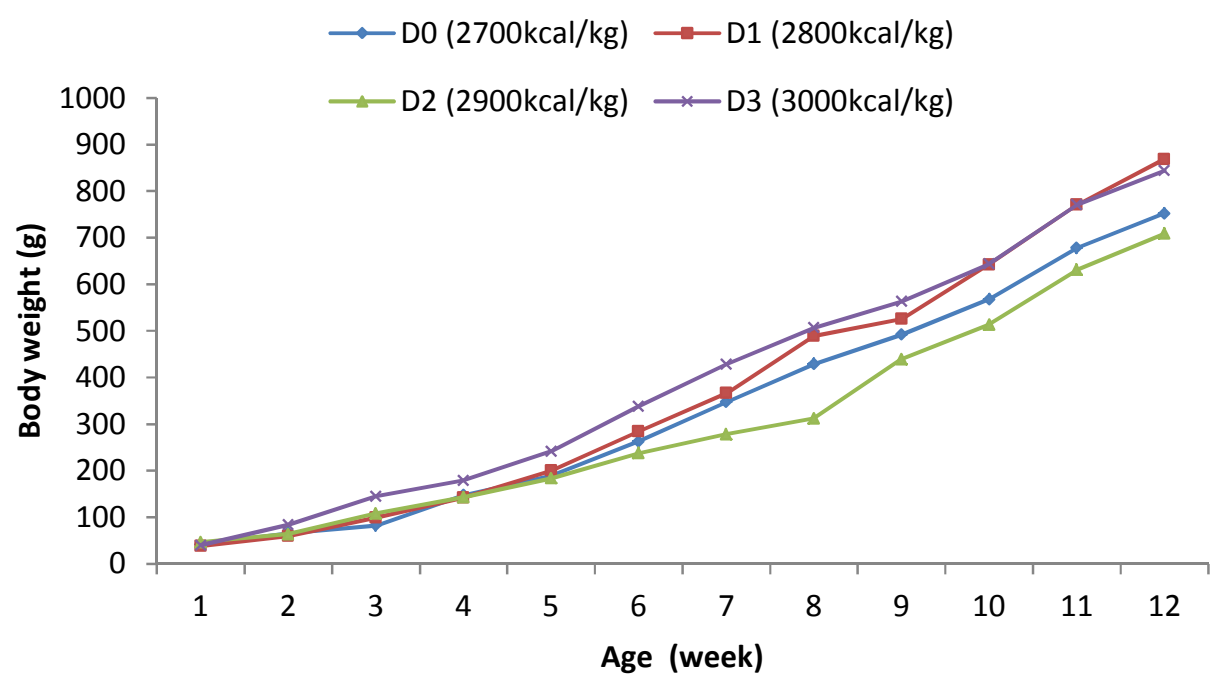

Figure 1: Growth curve of local barred chicks fed graded energy levels. 
H. M. KUIETCHE et al. / Int. J. Biol. Chem. Sci. 8(3): 882-890, 2014

Table 1: Composition and chemical characteristics of experimental diets.

\begin{tabular}{|c|c|c|c|c|}
\hline \multirow[b]{2}{*}{ Composition (kg) } & \multicolumn{4}{|c|}{ Experimental diets } \\
\hline & $\begin{array}{c}\text { D0 } \\
(2700 \mathrm{kcal} / \mathrm{kg})\end{array}$ & D1 (2800kcal/kg) & $\begin{array}{c}\text { D2 } \\
(2900 \mathrm{kcal} / \mathrm{kg})\end{array}$ & D3 (3000kcal/kg) \\
\hline Corn meal & 40.0 & 45.0 & 43.0 & 45.0 \\
\hline Wheat bran & 25.0 & 19.0 & 20.0 & 19.0 \\
\hline Cotton seed cake & 8.0 & 8.0 & 8.0 & 3.5 \\
\hline Soybean cake & 15.5 & 15.5 & 15.0 & 15.9 \\
\hline Fish meal & 5.0 & 6.0 & 6.0 & 8.0 \\
\hline Shellfish powder & 1.5 & 1.5 & 1.5 & 1.0 \\
\hline Premix $5 \% *$ & 5.0 & 5.0 & 5.0 & 5.0 \\
\hline Palm oil & 0.0 & 0.0 & 1.5 & 3.0 \\
\hline Total & 100.0 & 100.0 & 100.0 & 100.0 \\
\hline \multicolumn{5}{|l|}{ Calculated chemical composition } \\
\hline Crude protein $(\%)$ & 23.0 & 23.2 & 23.4 & 23.0 \\
\hline Metabolisable Energy (kcal/kg) & 2715 & 2813 & 2906 & 3010 \\
\hline Calcium $(\%)$ & 1.49 & 1.48 & 1.49 & 1.42 \\
\hline Phosphorus (\%) & 0.76 & 0.69 & 0.71 & 0.75 \\
\hline Lysine $(\%)$ & 1.31 & 1.29 & 1.49 & 1.34 \\
\hline Methionine (\%) & 0.43 & 0.43 & 0.43 & 0.45 \\
\hline Price $^{* *}(\mathrm{Fcfa} / \mathrm{kg})$ & 242 & 236 & 243 & 247 \\
\hline
\end{tabular}

premix 5\%: crude protein $=40 \%$; metabolisable Energy $=2078 \mathrm{kcal} / \mathrm{kg} ;$ Calcium $=8 \% ;$ Phosphor $=2.05 \% ;$ Lysine $=3.30 \%$; Methionine $=2.40 \%{ }^{* *} 1 \mathrm{USD}=485.43 \mathrm{Fcfa}$ 
Table 2: Effect of energy level on growth performances and the cost of feed per kg body weight of local barred chicks at started phase $(1-12$ week of age).

\begin{tabular}{lccccc}
\hline Parameters & \multicolumn{2}{c}{ Experimental diets } & \multicolumn{2}{c}{ P } \\
\cline { 2 - 5 } & D0 (2700kcal/kg) & D1 (2800kcal/kg) & D2 (2900kcal/kg) & D3 (3000kcal/kg) & \\
\hline Feed intake (g) & $3624.42 \pm 211.48^{\mathrm{a}}$ & $3198.94 \pm 179.38^{\mathrm{a}}$ & $3169.75 \pm 165.69^{\mathrm{a}}$ & $3338.00 \pm 169.11^{\mathrm{a}}$ & 0.297 \\
Body weight (g) & $752.09 \pm 88.10^{\mathrm{a}}$ & $868.81 \pm 34.47^{\mathrm{b}}$ & $708.63 \pm 14.83^{\mathrm{a}}$ & $844.08 \pm 55.95^{\mathrm{b}}$ & 0.003 \\
Body weight gain (g) & $710.78 \pm 84.47^{\mathrm{a}}$ & $830.78 \pm 35.53^{\mathrm{b}}$ & $662.20 \pm 14.90^{\mathrm{a}}$ & $804.33 \pm 59.78^{\mathrm{b}}$ & 0.003 \\
Feed conversion ratio (g/g) & $5.07 \pm 0.34^{\mathrm{b}}$ & $3.82 \pm 0.26^{\mathrm{a}}$ & $4.79 \pm 0.07^{\mathrm{b}}$ & $4.16 \pm 0.32^{\mathrm{a}}$ & 0.000 \\
FC (Fcfa) & $1228.36 \pm 81.52^{\mathrm{c}}$ & $901.86 \pm 62.00^{\mathrm{a}}$ & $1161.54 \pm 17.00^{\mathrm{c}}$ & $1027.55 \pm 78.09^{\mathrm{b}}$ & 0.000 \\
\hline
\end{tabular}

a,b and c: Means within the same row with a different superscript are different $(\mathrm{P}<0.05)$. 
Table 3: Effect of energy level on body morphometric parameters of local barred chicks at started phase (1-12 weeks of age).

\begin{tabular}{|c|c|c|c|c|c|}
\hline \multirow{2}{*}{$\begin{array}{l}\text { Morphometric } \\
\text { parameters (cm) }\end{array}$} & \multicolumn{4}{|c|}{ Experimental Diets } & \multirow[t]{2}{*}{$\mathbf{P}$} \\
\hline & $\begin{array}{c}\text { D0 } \\
(2700 \\
\mathrm{kcal} / \mathrm{kg})\end{array}$ & $\begin{array}{c}\text { D1 } \\
(2800 \\
\text { kcal/kg) }\end{array}$ & $\begin{array}{c}\text { D2 } \\
(2900 \mathrm{kcal} / \mathrm{kg})\end{array}$ & $\begin{array}{c}\text { D3 } \\
(3000 \mathrm{kcal} / \mathrm{kg})\end{array}$ & \\
\hline Wing Length & $20.45 \pm 1.75^{\mathrm{a}}$ & $19.90 \pm 1.74^{\mathrm{a}}$ & $18.26 \pm 0.78^{b}$ & $20.20 \pm 1.35^{\mathrm{a}}$ & 0.002 \\
\hline Foot length & $23.66 \pm 1.52^{\mathrm{b}}$ & $26.10 \pm 3.3^{\mathrm{a}}$ & $26.94 \pm 1.97^{\mathrm{a}}$ & $24.62 \pm 1.46^{\mathrm{b}}$ & 0.000 \\
\hline Tarsus length & $7.27 \pm 0.64^{\mathrm{bc}}$ & $7.48 \pm 0.69^{\mathrm{ab}}$ & $6.93 \pm 0.58^{\mathrm{c}}$ & $7.78 \pm 0.48^{\mathrm{a}}$ & 0.000 \\
\hline Tarsus diameter & $1.03 \pm 0.17^{\mathrm{a}}$ & $1.05 \pm 0.13^{\mathrm{a}}$ & $0.90 \pm 0.07^{\mathrm{b}}$ & $1.07 \pm 0.10^{\mathrm{a}}$ & 0.005 \\
\hline Body length & $29.71 \pm 1.91^{\mathrm{bc}}$ & $31.09 \pm 2.92^{\mathrm{ab}}$ & $28.74 \pm 2.79^{c}$ & $32.12 \pm 1.92^{\mathrm{a}}$ & 0.000 \\
\hline Head length & $5.84 \pm 0.57^{\mathrm{a}}$ & $4.38 \pm 0.28^{\mathrm{b}}$ & $4.00 \pm 0.22^{\mathrm{c}}$ & $4.30 \pm 0.28^{\mathrm{b}}$ & 0.000 \\
\hline Beak length & $3.29 \pm 0.41^{\mathrm{a}}$ & $3.25 \pm 0.26^{\mathrm{a}}$ & $3.07 \pm 0.11^{\mathrm{b}}$ & $3.26 \pm 0.18^{\mathrm{a}}$ & 0.193 \\
\hline Body girth & $23.08 \pm 1.52^{\mathrm{b}}$ & $24.56 \pm 1.94^{\mathrm{a}}$ & $23.93 \pm 1.04^{\mathrm{ab}}$ & $24.08 \pm 1.64^{\mathrm{ab}}$ & 0.009 \\
\hline Comb Height & $1.03 \pm 0.69^{\mathrm{a}}$ & $1.11 \pm 0.67^{\mathrm{a}}$ & $0.80 \pm 0.35^{\mathrm{a}}$ & $1.12 \pm 0.64^{\mathrm{a}}$ & 0.538 \\
\hline Comb length & $2.52 \pm 0.78^{\mathrm{a}}$ & $2.69 \pm 1.00^{\mathrm{a}}$ & $2.23 \pm 0.48^{\mathrm{a}}$ & $2.81 \pm 1.02^{\mathrm{a}}$ & 0.283 \\
\hline Wattle height & $1.23 \pm 0.60^{\mathrm{a}}$ & $1.26 \pm 0.35^{\mathrm{a}}$ & $1.02 \pm 0.33^{\mathrm{a}}$ & $1.31 \pm 0.42^{\mathrm{a}}$ & 0.341 \\
\hline
\end{tabular}

$\mathrm{a}, \mathrm{b}, \mathrm{c}$ : Means within the same row with a different superscript are different $(\mathrm{P}<0.05)$.

\section{DISCUSSION}

Within the limits of the experimental conditions imposed, during the twelve-weeks growth period (1 to 12 weeks) feed intake was not significantly affected $(\mathrm{P}>0.05)$ by dietary energy level. This finding, while being consistent with that of Nguyen and Bunchasak (2005), on the Thailand Betong native chicken and Magala et al. (2012) on Uganda local chickens, was different from the observations of Niu et al. (2009), Alabi et al. (2013) on commercial broilers and Venda chicks respectively. This may be due to breed differences which have different gene encoding key regulatory factors such as hormones, enzymes and metabolic pathways (Richards and Proszkowiec-Weglarz, 2007; Tang et al., 2007). Emmans and Fisher (1986) and Emmans (1989) indicated that chickens grow based on their genetic potential; thus, they attempt to eat as much of a given feed as would be required to satisfy their growth needs. However, the present result is in agreement with NRC (1994) which reported that it is not always accurate to conclude that poultry feed intake is adjust to achieve a minimum energy intake from diets. On the other hand, it may be assumed that the energy contents between 2700-3000 ME kcal/ $/ \mathrm{kg}$ met or exceeded the requirement of the barred chicks, so that subsequent varying energy levels did not affect feed intake.

Life body weight, body weight gain, feed conversion ratio and feed cost $/ \mathrm{kg}$ of meat were significantly affected $(\mathrm{P}<0.05)$ by the different dietary regimes. Diet D1 and D3 with 2813 and $3010 \mathrm{kcal} / \mathrm{kg}$ of metabolisable energy respectively exhibited the greatest BW, BWG and the lowest FCR as compared to D0 $(2715 \mathrm{kcal})$ and D2 (2906 kcal). This is consistent with the findings of Saleh et al. (2004), Ghazalah et al. (2008) and Alabi et al. (2013) who obtained improved FCR with increasing energy level. Furthermore, several researches have shown that growth parameters are influenced by changes in dietary energy concentration in two partially dependent pathways. Firstly, as dietary energy increases, feed efficiency is improved as less feed is taken in to satisfy the energy needs of the chickens and secondly, growth rate is promoted by increasing levels of dietary energy as reported by Plavnik et al. (1997), Yalcin et al. (1998) and Dublecz et al. (1999). 
In addition, the faster growth rate of chicks fed with high metabolizable energy diet may be due to the use of energy for efficient retention of protein; since protein is the building blocks needed for growth (Moreng and Avens, 1985). The improvement in response to dietary energy during the starter phase were further shown by the reports of Maiorka et al. (2004) who observed improved body weight and FCR with increased dietary energy in the starter period. The present result disagrees the reports of Nguyen and Bunchasak (2005) on the Betong chicken, Hidalgo et al. (2004), Dozier et al. (2008) and Niu et al. (2009) on broiler chicks and Engku et al. (2011) on Kampung chicks.

The economic evaluation shows that the mean feed cost necessary to produce a $\mathrm{kg}$ of body weight is significantly $(\mathrm{P}<0.05)$ lower in D1 as compared to D0, D2 and D3. Variations in energy level from 2700 to 2800 $\mathrm{kcal}$ lead to reduction in $270.21 \mathrm{Fcfa}$ in cost of production. It can be explained by the fact that consumption index reduce significantly between D0 (2700 kcal), D1 (2800 kcal) and D3 (3000 kcal). This is consistent with the findings of Mafouo et al. (2011) who obtained a reduction in cost of production with reduction in consumption index.

Increasing the energy level of the diet tends to increase the values of body measurements in the starter phase; this is due to the fact that morphometric characteristics have a direct relationship with body weight in poultry (Ige et al., 2006; Ogah, 2011). Hence, increasing in dietary energy level lead to higher body measurements.

\section{Conclusion}

Optimal response in feed intake, growth rate, feed conversion ratio in local barred chickens increase with an increased in dietary energy level. Body morphometric parameter tends to increase with an increased dietary energy level. Therefore, $2800 \mathrm{kcal} / \mathrm{kg}$ should be adopted as metabolisable energy requirement for local barred chicks at early growth period.

\section{REFERENCES}

Alabi OJ, Ng'ambi JW, Norris D. 2013. Dietary energy level for optimum productivity and carcass characteristics of indigenous Venda chickens raised in closed confinement. S. Afr. J. Anim. Sci., 43(1): 75-80.

Ayayi OO, Adeleke MA, Sanni MT, Yakubu A, Peters SO, Imumorin IG, Ozoje MO, Ikeobi CON, Adebambo OA. 2012. Application of factor and discriminant analyses to morpho-structural indices of indigenous and exotic chickens raised under intensive management system. Trop. Anim. Heath. Prod., 44: 1247-1254.

Dozier WA, Corzo III A, Kidd MT. 2008. Apparent metabolizable energy needs of broiler chicks subjected to diverse ambient temperature regimens. J. Appl. Poult. Res., 17: 134-140.

Dublecz K, Vincze L, Szuts G, Wagner L, Pal L, Bartos A. 1999. Effect of dietary energy level on the performance of broiler chicks. Proceedings $12^{\text {th }}$ European Symposium on Poultry Nutrition.WPSAVelthoven. Netherlands. 15-19 August 1999; 424-426.

Emmans GC, Fisher C. 1986. Problems in nutritional theory. In Nutrient Requirements of Poultry and Nutritional Research, Fisher C, Boorman KN (eds). Butter worths Emmans \& Fisher: London; 9-39.

Emmans GC. 1989. The growth of turkeys. In: Recent Advances in Turkey Science, Nixey C, Grey TC (eds). Butterworths: London; 135-166.

Engku Azahan EA. 2007. Responses of commercial kampong chickens to varying dietary energy levels in the finishing growth phases. Proceedings. 28th MSAP Annual Conference, 139-140.

Engku Azahan EA, Azlina Azma IA, Noraziah M. 2011. Growth response of crossbred village (kampung) chickens to starter diets of differing energy contents. Mal. J. Anim. Sci., 14: 51-55. 
Ghazalah AA, Abd-Elsamee MO, Ali AM. 2008. Influence of dietary energy and poultry fat on the response of broiler chicks to heat therm. Int. J. Poult. Sci., 74: 355-359.

Hidalgo MA, Dozier WAIII, Davis AJ, Gordon RW. 2004. Live performance and meat yield responses of broilers to progressive concentrations of dietary energy maintained at a constant metabolisable energy-to-crude protein ratio. J. Appl. Poult. Res., 13: 319-327.

Ige AO, Akinlade JA, Ojedapo LO, Oladunjoye IO, Amao SR, Animashaun AO. 2006. Effect of sex on interrelationship between body weight and linear body measurements of commercial broilers in a derived savannah environment of Nigeria. Proc. $11^{\text {th }}$ Annual Conference of the Animal Science Association of Nigeria. 18- 21 Sept 2006. Ibadan. Oyo State.Nigeria, 231-243.

Kana JR, Kreman K, Mube KH, Teguia A, Manjeli Y 2013. Effect of substituting maize with cassava root meal on laying performances of local barred-chicken under improved management conditions in Cameroon. Livestock Research for Rural Development, 25: Article \#177. Retrieved April 5, 2014, from http://www.lrrd.org/lrrd25/10/kana25177. htm

Kana JR, Tadjong RN, Kuietche HM, Tefack Y, Zambou H, Teguia A 2014. Valorisation des résidus de manioc en substitution du maïs dans la ration alimentaire du poulet de chair. Livestock Research for Rural Development, 26: Article \#48. Retrieved May 5, 2014, from http://www.lrrd.org/lrrd26/3/kana26048.h tm

Kreman K, Kana JR, Defang FH,Teguia A. 2012. Effet de la substitution du maïs par le manioc dans l'aliment sur les performances de croissance et les caractéristiques de la carcasse de la poule locale du Cameroun. Bul. Anim. Health. Prod. Afr., 60: 303-311.

Mafouo Ngandjou H, Teguia A, Kana J R, Mube HK, Diarra M. 2011. Effet du niveau d'incorporation de la farine de manioc dans la ration sur les performances de croissance des poulets de chair. Livestock Research for Rural Development, 23 : Article \#76. Retrieved February 15, 2014, from http://www.lrrd. org/lrrd23/4/mafo23076.htm

Maiorka A, Dahlke F, Santin E, Kessler AM, Penz Jr AM. 2004. Effect of energy levels of diets formulated on total or digestible amino acids basis on broiler performance. Rev. Bras. Cienc. Avic., 6: 87-91.

Mbajiorgu CA, Ngambi JW, Norris D. 2011. Effect of varying dietary energy to protein ratio level on growth and productivity of indigenous Venda chickens. Asian J. Anim. Vet. Adv., 6(4): 344-352.

McDonald P, Edwards RA, Greenhalgh JFD, Morgan CA, Sinclair LA, Wilkinson RG. 2011. Animal Nutrition ( $7^{\text {th }}$ edn). Prentice Hall: London.

Mtileni BJ, Muchadeyi FC, Maiwashe A, Chimonyo M, Dzama K. 2012. Conservation and utilization of indigenous chicken in Southern Africa. World. Poult. Sci. J., 68: 727-747.

Magala H, Kugonza DR, Kwizera H, Kyarisiima CC. 2012. Influence of Varying Dietary Energy and Protein on Growth and Carcass Characteristics of Ugandan Local Chickens. J. Anim. Prod. $A d v ., 2(7): 316-324$

Moreng RE, Avens JS. 1985. Poultry Science and Production. Reston Publishing Company, Inc.: Reston, Virginia; 203234.

National Research Council (NRC). 1994. Nutrient Requirements of Poultry. $\left(9^{\text {th }}\right.$ revised edn). National Academy Press: Washington. DC.

Nguyen TV, Bunchasak C. 2005. Effects of dietary protein and energy on growth performance and carcass characteristics 
of Betong chicken at early growth stage. Songklanakarin J. Sci. Technol., 27(6): 1171-1178.

Niu Z, Shi J, Liu F, Wang X, Gao C, Yao L. 2009. Effects of dietary energy and protein on growth performance and carcass quality of broilers during starter phase. Int. J. Poult. Sci., 8(5): 508-511.

Ogah DM. 2011. In vivo prediction of live weight and carcass traits using body measurements in indigenous guinea fowl. Biotechnol. Anim. Husb., 27(4). 18271836.

Plavnik I, Wax E, Sklan D, Bartov I, Hurwitz S. 1997. The response of broiler chickens and turkey poultry to dietary energy supplied either by fat or carbohydrates. Poult Sci., 76: 1000-1005.

Proszkowiec-Weglarz M, Richards MP. 2007. Mechanisms regulating feed intake, energy expenditure and body weight in poultry. Poult. Sci., 86, 1478-1490.

Saleh EA, Watkins SE, Waldroup AL, Waldroup PW. 2004. Effects of dietary nutrient density on performance and carcass quality of male broilers grown for further processing. Int. J. Poult. Sci., 3:110 .

Sizemore FG, Siegel HS. 1993. Growth, feed conversion and carcass composition in females of four broiler crosses fed starter diets with different energy levels and energy to protein ratios. Poult. Sci., 72: 2216-2228.
Steel RDG, Torrie JH. 1980. Principles and Procedures of Statistics. McGraw-Hill Book Company, Inc.: New York.

Tang MY, Ma QG, Chen ZD, Ji C. 2007. Effects of dietary metabolizable energy and lysine on carcass characteristics and meat quality in arbor acres broilers. Asian-Australian J. Anim. Sci., 20: 18651873.

Tewe OO, Bokanga M, Dixon AGO, Larbi A. 2002. Strategies for cost effective cassava plant based feeds for livestock and fish production in Africa. Paper presented at the Regional workshop on improving the cassava sub-sector. April 2002, Nairobi, Kenya, p. 7.

Yakubu A, Salako AE. 2009. Path coefficient analysis of body weight and morphological triats of Nigeria indigenous chickens. Egypt. Poult. Sci., 29(3): 837-850.

Yalcin S, Ozkan S, Acikgoz Z, Ozkan K. 1998. Influence of dietary energy on bird performance, carcass parts yields and nutrient composition of breast meat of heterozygous naked neck broilers reared at natural optimum and summer temperatures. Brit. Poult. Sci., 39: 633638.

Yamane T, Ono K, Tanaka T. 1980. Energy requirements of laying Japanese quail. Bras. Poult. Sci., 21: 451-455. 